\title{
Anti-NMDAR Encephalitis in the Netherlands, Focusing on Late-Onset Patients and Antibody Test Accuracy
}

Anna E.M. Bastiaansen, MD, Marienke A.A.M. de Bruijn, MD, PhD, Sabine L. Schuller, BSc, Eugenia Martinez-Hernandez, MD, PhD, Juliëtte Brenner, MD, Manuela Paunovic, PhD, Yvette S. Crijnen, MD, Maxim J.H.L. Mulder, MD, PhD, Marco W.J. Schreurs, PhD, Esther de Graaff, PhD, Peter A.E. Smitt, MD, PhD, Rinze F. Neuteboom, MD, PhD, Juna M. de Vries, MD, PhD, and Maarten J. Titulaer, MD, PhD

Neurol Neuroimmunol Neuroinflamm 2022;9:e1127. doi:10.1212/NXI.0000000000001127

\section{Abstract}

\section{Background and Objectives}

To describe the clinical features of anti-NMDAR encephalitis, emphasizing on late-onset patients and antibody test characteristics in serum and CSF.

\section{Methods}

Nationwide observational Dutch cohort study, in patients diagnosed with anti-NMDAR encephalitis between 2007 and 2019.

\section{Results}

One hundred twenty-six patients with anti-NMDAR encephalitis were included with a median age of 24 years (range 1-86 years). The mean annual incidence was $1.00 /$ million (95\% CI $0.62-1.59)$. Patients $\geq 45$ years of age at onset (19\%) had fewer seizures ( $46 \%$ vs $71 \%, p=$ 0.021 ), fewer symptoms during disease course ( 3 vs 6 symptoms, $p=0.020$ ), and more often undetectable serum antibodies compared with younger patients $(p=0.031)$. In the late-onset group, outcome was worse, and all tumors were carcinomas (both $p<0.0001$ ). CSF was more accurate than serum to detect anti-NMDAR encephalitis (sensitivity $99 \%$ vs $68 \%, p<0.0001$ ). Using cell-based assay (CBA), CSF provided an unconfirmed positive test result in 11/2,600 patients $(0.4 \%) ; 6 / 11$ had a neuroinflammatory disease (other than anti-NMDAR encephalitis). Patients with anti-NMDAR encephalitis, who tested positive in CSF only, had lower CSF antibody titers $(p=0.003)$, but appeared to have an equally severe disease course.

\section{Discussion}

Anti-NMDAR encephalitis occurs at all ages and is less rare in the elderly patients than initially anticipated. In older patients, the clinical phenotype is less outspoken, has different tumor association, and a less favorable recovery. Detection of antibodies in CSF is the gold standard, and although the CBA has very good validity, it is not perfect. The clinical phenotype should be leading, and confirmation in a research laboratory is recommended, when in doubt.

\author{
Correspondence \\ Dr. Titulaer \\ m.titulaer@erasmusmc.nl
}




\section{Glossary}

AIE = autoimmune encephalitis; $\mathbf{C B A}=$ cell-based assay; $\mathbf{C J D}=$ Creutzfeldt-Jakob disease $; \mathbf{H S V}=$ herpes simplex virus; $\mathbf{I C U}=$ intensive care unit; IHC = immunohistochemistry; IQR = interquartile range; $\mathbf{L N}=$ live hippocampal neurons; $\mathbf{m R S}=$ modified Rankin Scale; NMDAR = anti-NMDA receptor; $\mathbf{P P V}=$ positive predictive value.

Anti-NMDA receptor (NMDAR) encephalitis is a severe immune-mediated disorder, and patients generally respond well to immunotherapy. ${ }^{1}$ Fast initiation of immunotherapy is associated with a better clinical outcome. ${ }^{1-3}$ Marking a timely diagnosis of anti-NMDAR encephalitis can be challenging because patients can present with less notable encephalitis signs, as suggested in late-onset patients (over 45 years of age at onset). ${ }^{4}$ NMDAR antibody testing may lead to misleading results, when only serum is tested. Diagnosis might be missed as antibodies can be only detectable in CSF in $15 \%$ of the patients. ${ }^{5,6}$ In addition, serum can yield positive but unconfirmed results, ${ }^{7}$ as reported by earlier studies in healthy controls, patients with psychiatric conditions, or CreutzfeldtJakob disease (CJD) ${ }^{8-14}$ However until today, data involving unconfirmed antibody test results in CSF are missing. We report the pitfalls in the diagnosis of anti-NMDAR encephalitis, emphasizing on the clinical characteristics of late-onset patients, and antibody test accuracy in serum and CSF.

\section{Methods}

\section{Patients}

We performed a nationwide, partly retrospective cohort study in Dutch patients with anti-NMDAR encephalitis. Patients were identified between March 2007 and December 2019. The Department of Neurology of the Erasmus University Medical Center is a European Reference Network site and the national referral site for patients with suspected autoimmune encephalitis (AIE); the Laboratory Medical Immunology (Department of Immunology) is the EN ISO 15189;2012 accredited national referral site for antineuronal antibody testing. Therefore, we could identify all patients with positive NMDAR antibodies, and each patient was asked to participate. Part of the children with anti-NMDAR encephalitis were described before. ${ }^{15}$ Late onset was defined as age at onset $\geq 45$ years. ${ }^{4}$ Antibodies were detected in serum and/or in CSF using commercial cell-based assay (CBA, Euroimmun AG, Lübeck, Germany), and when in doubt by in-house CBA as well. Antibodies detected by CBA were confirmed with alternative antibody tests based on immunohistochemistry (IHC) and live hippocampal neurons (LN) as described before. ${ }^{6,16}$ If a sample was tested positive by CBA, but the positive result could not be confirmed by neither IHC nor LN, we defined that sample as unconfirmed. Those unconfirmed CSF samples were sent for additional confirmation to the laboratory of Professor Dalmau (Hospital Clinic, University of Barcelona, Spain) and in-house CBA, IHC and LN were performed. ${ }^{17}$ Antibody titers were determined by IHC of pretreatment serum and CSF samples. ${ }^{6}$

\section{Clinical Information}

Clinical patient data about the disease course were obtained from detailed interviews with patients or relatives during a visit to our clinic in addition to the medical records ( $81 \%)$ or from medical records only (19\%). Level of functioning was measured with the modified Rankin Scale (mRS). ${ }^{18}$ Failure to firstline treatment was considered if no clinical improvement occurred within 2 weeks from start of immunotherapy.

To determine whether final diagnoses were concordant with antibody results and assess whether our confirmatory tests were accurate, we analyzed all patients with positive antiNMDAR CBA, including those in whom we could not confirm CSF antibodies by additional tests.

\section{Standard Protocol Approvals, Registrations, and Patient Consents}

This retrospective study was waived and declared non-WMO complicit by the Institutional Review Board of Erasmus MC. Written informed consent was obtained from all patients.

\section{Statistics}

Statistical analysis was performed using IBM SPSS 25.0 (SPSS Inc) for Windows and Prism 8.4.3. (GraphPad). For group comparisons, using categorical data, we used the Pearson $\chi^{2}$ test or the Fisher exact test when appropriate. Continuous data were analyzed using the Student $t$ test or the Mann-Whitney $U$ test, when appropriate. The annual incidence rate was calculated with $95 \%$ CI assuming a Poisson distribution, and Dutch population data were used from StatLine (opendata.cbs.nl/\#/CBS/nl/). Diagnostic test evaluation was compared using the $\mathrm{McNemar}$ paired test and $\chi^{2}$ test for proportions. Seasonal patterns were analyzed using directional, circular statistics, and significance was determined by Rayleigh Z statistics. ${ }^{19}$ We applied no correction for multiple testing, and therefore, $p$ values between 0.05 and 0.005 should be considered with care.

\section{Data Availability}

Any data not published within this article are available at the Erasmus University Medical Center. Patient-related data will be shared on reasonable request from any qualified investigator, maintaining anonymization of the individual patients.

\section{Results}

\section{Incidence and Cohort Description}

The anti-NMDAR encephalitis cohort consisted of 133 patients, identified between 2007 and 2019, of whom 126 consented to study participation and were included in this study. In the 

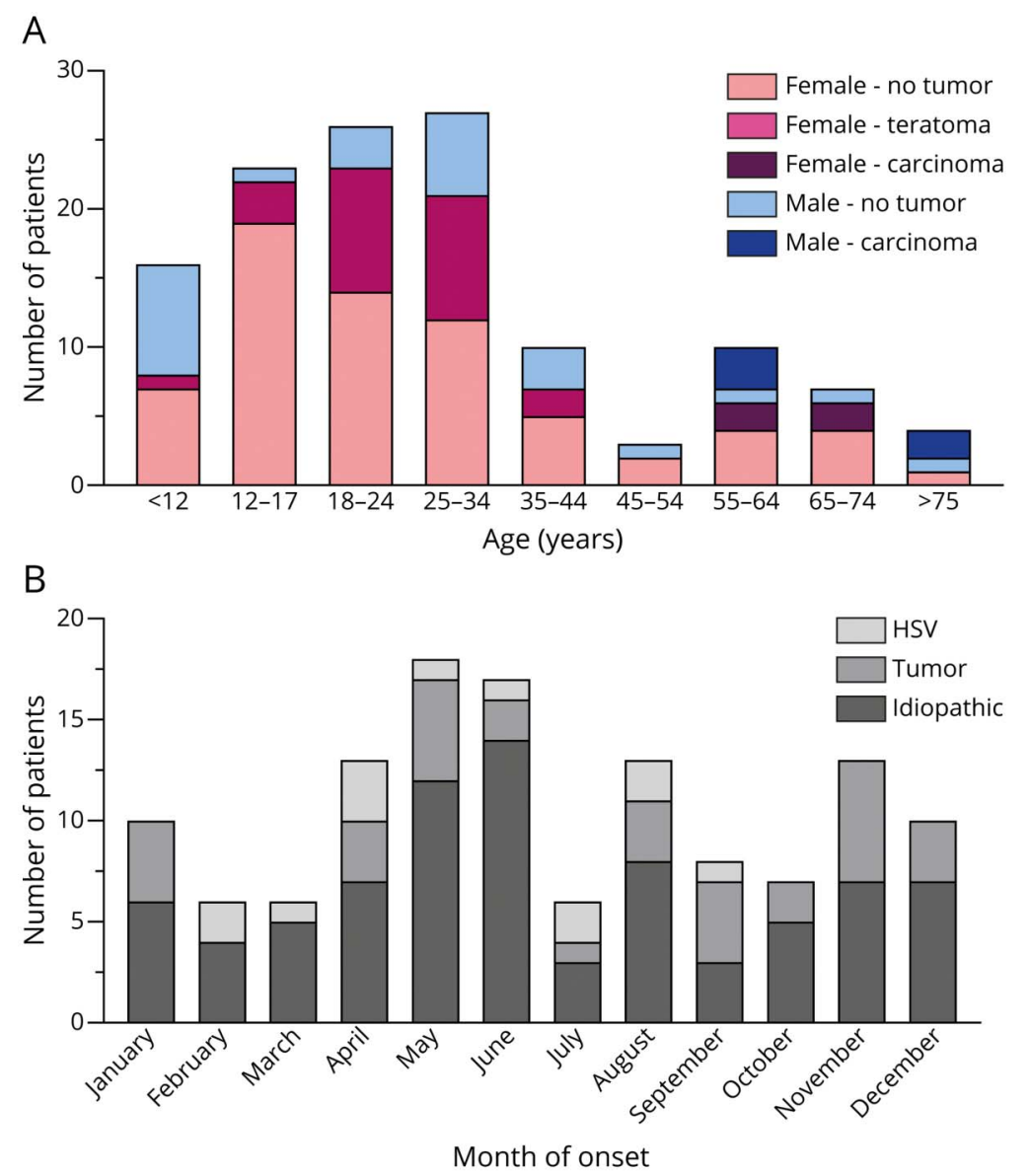

The figure involves the total cohort of 126 patients with antiNMDAR encephalitis. (A) Age and tumor distribution. All tumors in patients aged $\geq 45$ years were carcinomas, and in patients aged $<45$ years, all were teratomas. The age categories $<25$ years have a different age distribution compared with other age categories. (B) Seasonal influences in antiNMDAR encephalitis. The figure shows the month of onset divided by etiology (idiopathic, post-HSV, or tumor); $Z=1.80$ $(p<0.20)$ using Rayleigh Z statistics (data not shown). Figure

Month of onset is similar for the 2015-2019 subcohort (data not shown).

period from May 2015 to December 2019, we identified 79 patients with a mean incidence rate of $1.00 /$ million (95\% CI 0.62-1.59). The annual incidence rate of anti-NMDAR encephalitis in 5 consecutive years is shown in eTable 1, links.lww. com/NXI/A674 showing a peak in 2017. There was a predominance of onset in May and June (Figure 1B), although this did not reach statistical significance (circular direction would aim at May 24, $\mathrm{Z}=1.80, p<0.20$; eFigure 1, links.lww.com/NXI/ A674); Exploring patients with anti-NMDAR encephalitis without known trigger (no HSV, nor paraneoplastic origin), a tendency toward seasonal variance was seen, pointing toward May (circular direction May 11, Z = 2.55, $p<0.10$ ).

The median age at onset was 24 years (IQR $17-38$ years), and 39 patients (31\%) were children. Twenty-four patients (19\%) were aged 45 years or older at disease onset (Figure 1A). There was a known female predominance (76\%), mainly for patients $12-45$ years $(73 / 86[85 \%]$ vs $8 / 16[50 \%] 0-12$ years vs $15 / 24$ [63\%] $\geq 45$ years, $p=0.002$ ). It took a median of 26 days (IQR $16-53$ days) from disease onset to diagnosis. Details are provided in eTable 2, links.lww.com/NXI/A674. Almost all patients were treated with first-line immunotherapy $(\mathrm{n}=123,98 \%)$ and 51 patients $(41 \%)$ with second-line treatment. Patients were treated after a median of 21 days (IQR 11-45 days) from symptom onset, and it took a median of 46 days (IQR 29-89 days) to the first signs of clinical improvement (from symptom onset). Sixty-seven patients (55\%) showed no response to firstline immunotherapy within 2 weeks. After the first signs of recovery, patients became independent in their daily activities ( $\mathrm{mRS}$ score $\leq 2)$ after a median of 5 months from disease onset (IQR 2-10 months). Three-quarters $(\mathrm{n}=87)$ showed good functional outcome (as measured by the mRS) at 12 months.

\section{Late-Onset Patients}

The median age of the 24 patients with disease onset $\geq 45$ years of age was 64 years (range $46-86$ years). Behavioral problems, seizures, and sleep disorders occurred less frequently in patients aged $\geq 45$ years $(p=0.042, p=0.021$, and $p=0.003$, respectively, Table 1), as was the cumulative number of symptoms (median $3 \mathrm{vs}$ $6, p=0.020)$. The maximum severity of the disease $(\mathrm{mRS})$ and the need for ICU support were similar in late-onset patients compared with younger patients (Table 2). Nine patients (38\%) had an underlying tumor, all carcinomas, whereas in younger patients, only teratomas were detected $(p<0.0001$; Figure $1 \mathrm{~A})$. Abnormalities in ancillary testing typical for anti-NMDAR encephalitis showed no differences between both groups. In addition, median serum and CSF titers were similar between late-onset and younger patients. However, the patients aged 
Table 1 Clinical Features of Patients With Anti-NMDAR Encephalitis (Defined by the Age at Onset)

\begin{tabular}{|c|c|c|c|}
\hline & Age $<45$ y $(n=102)$ & Age $\geq 45$ y $(n=24)$ & $p$ Value \\
\hline Sex, female & $81(79 \%)$ & $15(63 \%)$ & 0.080 \\
\hline Age at onset (mean, SD) & $21(10.2)$ & $64(9.5)$ & $<0.0001$ \\
\hline Onset to diagnosis, $d$ (median, IQR, range) & $26(16-48,5-5,845)$ & $25(16-88,5-210)$ & 0.74 \\
\hline \multicolumn{4}{|l|}{ Symptoms } \\
\hline Behavioral changes & $98(96 \%)$ & $20(83 \%)$ & 0.042 \\
\hline Cognitive decline & $88(86 \%)$ & $22(92 \%)$ & 0.74 \\
\hline Speech problems & $66(65 \%)$ & $14(58 \%)$ & 0.56 \\
\hline Seizures & $72(71 \%)$ & $11(46 \%)$ & 0.021 \\
\hline Movement disorders & $67(66 \%)$ & $12(50 \%)$ & 0.15 \\
\hline Awareness problems & $51(50 \%)$ & $8(33 \%)$ & 0.14 \\
\hline Autonomic symptoms & $45(44 \%)$ & $7(30 \%)$ & 0.23 \\
\hline Hypoventilation & $24(24 \%)$ & $7(29 \%)$ & 0.56 \\
\hline Sleep disorders & $51(51 \%)$ & $4(17 \%)$ & 0.003 \\
\hline Number of symptoms (median, IQR, range) & $6(4-7,0-9)$ & $3(2-7,1-9)$ & 0.020 \\
\hline \multicolumn{4}{|l|}{ Ancillary testing } \\
\hline CSF abnormal & $84(86 \%)$ & $19(83 \%)$ & 0.75 \\
\hline WBC elevated & $74(76 \%)$ & $18(78 \%)$ & 0.78 \\
\hline WBC (median, IQR, range) & $18(5-47,0-267)$ & $23(6-66,2-235)$ & 0.53 \\
\hline Total protein elevated & $20(21 \%)$ & $8(36 \%)$ & 0.17 \\
\hline IgG index elevated & $10 / 33(30 \%)$ & $2 / 6(33 \%)$ & \\
\hline Oligoclonal bands present & $27 / 36(75 \%)$ & $3 / 4(75 \%)$ & \\
\hline Antibody titer CSF ( $n=106$; median, IQR, range) & $1: 32(1: 16-1: 128)$ & $1: 64(1: 8-1: 512$, neg-1:2048) & 0.36 \\
\hline Antibody titer serum ( $n=104$; median, IQR, range) & $1: 800(1: 200-1: 1,600,1: 100-1: 6,400)$ & $1: 200(1: 100-1: 1,600,1: 100-1: 12,800)$ & 0.27 \\
\hline Seronegative NMDAR antibody ${ }^{a}$ & $9 / 89(10 \%)$ & $6 / 20(30 \%)$ & 0.031 \\
\hline MRI abnormalities AIE related & $22 / 99(31 \%)$ & $7 / 23(30 \%)$ & 0.69 \\
\hline EEG abnormal & $84 / 91(92 \%)$ & $15 / 19(79 \%)$ & 0.10 \\
\hline Posterior rhythm abnormal & $27 / 77(35 \%)$ & $5 / 17(29 \%)$ & 0.78 \\
\hline Tumor & $24(24 \%)$ & $9(38 \%)$ & 0.19 \\
\hline Teratomas & $24 / 102$ & $0 / 24$ & 0.007 \\
\hline Carcinomas & $0 / 102$ & $9 / 24(38 \%)$ & $<0.0001$ \\
\hline Post-HSV & $9(9 \%)$ & $4(17 \%)$ & 0.27 \\
\hline
\end{tabular}

Abbreviations: $\mathrm{AIE}=$ autoimmune encephalitis; IQR = interquartile range; $\mathrm{HSV}=$ herpes simplex virus; $\mathrm{WBC}=$ white blood cell count.

Data are $\mathrm{n}(\%), \mathrm{n} / \mathrm{n}(\%)$, mean (SD), or median (interquartile range, range).

$P$ values $<0.05$ are shown in bold.

a Serum was tested negative both by CBA and IHC.

$\geq 45$ years had more often antibodies detectable only in CSF (seronegative; $30 \%$ vs $10 \%$ in younger adults, $p=0.031$ ).

First-line immunotherapy and second-line immunotherapy were evenly used in late-onset and younger patients, and there were no differences between both groups in the time until start of treatment and in failure to first-line immunotherapy (Table 2). Regarding outcome, patients aged $\geq 45$ years had a worse outcome. Functional independence ( $\mathrm{mRS}$ score $\leq 2$ ) was only achieved at a median of 12 months (IQR 5-13 months) for the patients aged $\geq 45$ years, whereas this was 4 months for younger patients (IQR 2-7 months; $p=<0.0001$ ). After 1 year, 
Table 2 Treatment and Outcome in Patients With Anti-NMDAR Encephalitis (Defined by the Age at Onset)

\begin{tabular}{|c|c|c|c|}
\hline & Age $<45$ y $(n=102)$ & Age $\geq 45$ y $(n=24)$ & $p$ Value \\
\hline Hospital admission & $96(94 \%)$ & $24(100 \%)$ & 0.59 \\
\hline Hospital stay, d (median, IQR, range) & $55(24-83,0-551)$ & $46(26-87,7-262)$ & 0.71 \\
\hline Onset to admission (median, IQR, range) & $3(0-13,0-88)$ & $7(0-28,0-170)$ & 0.34 \\
\hline ICU admission & $50(49 \%)$ & $11(46 \%)$ & 0.82 \\
\hline ICU stay, d (median, IQR, range) & $28(4-49,1-307)$ & $36(5-71,2-132)$ & 0.39 \\
\hline \multicolumn{4}{|l|}{ Immunotherapy } \\
\hline First-line immunotherapy & $99(97 \%)$ & $24(100 \%)$ & 1.00 \\
\hline Onset to first-line IT, d (median, IQR, range) & $21(10-42,2-510)$ & $23(13-81,1-181)$ & 0.33 \\
\hline First-line IT to improvement, d (median, IQR, range) & $21(8-41,-383-774)^{\infty}$ & $14(7-37,5-93)$ & 0.79 \\
\hline Failure of first-line $\mathrm{IT}^{\mathrm{a}}$ & $55 / 98(56 \%)$ & $12 / 23(52 \%)$ & 0.73 \\
\hline Second-line immunotherapy & $44(43 \%)$ & $7(29 \%)$ & 0.21 \\
\hline Onset to second-line IT, d (median, IQR, range) & $31(23-61,12-822)$ & $38(31-214,26-310)$ & 0.13 \\
\hline \multicolumn{4}{|l|}{ Outcome } \\
\hline Onset to improvement, $d$ (median, IQR, range) & $44(30-79,1-974)$ & $90(25-195,7-366)$ & 0.20 \\
\hline Time to $\mathrm{mRS}$ score 2 , mo (median, IQR, range) & $4(2-7,0-$ not achieved $)$ & $12(5-13,1-$ not achieved) & $<0.0001$ \\
\hline mRS score max (median, IQR, range) & $4(3-5,2-5)$ & $4(3-5,3-5)$ & 0.99 \\
\hline mRS score at start IT (median, IQR, range) & $4(3-5,2-5)$ & $4(3-5,3-5)$ & 0.92 \\
\hline mRS score at 12 mo (median, IQR, range) & $2(1-2,0-6)$ & $3(2-6,0-6)$ & $<0.0001$ \\
\hline Poor outcome at last FU (mRS score $\geq 3$ ) & 15/101 (15\%) & $13 / 24(54 \%)$ & $<0.0001$ \\
\hline Relapse & $18(18 \%)$ & $4(17 \%)$ & 1.00 \\
\hline Deceased & $2(2 \%)$ & $9(38 \%)$ & $<0.0001$ \\
\hline
\end{tabular}

Abbreviations: FU = follow-up; ICU = intensive care unit; IQR = interquartile range; IT = immunotherapy; $\mathrm{mRS}=$ modified Rankin Scale.

Data are $\mathrm{n}(\%), \mathrm{n} / \mathrm{n}(\%)$, mean (SD), or median (interquartile range, range).

$P$ values $<0.05$ are shown in bold.

${ }^{\infty} 9$ patients showed clinical improvement before the start of immunotherapy, 7 of whom within 26 days before treatment. All were not completely recovered

for which immunotherapy was administered.

${ }^{a}$ Failure to first-line immunotherapy was defined as no clinical improvement within 2 weeks after the start of treatment.

$64 \%$ of the patients aged $\geq 45$ years had a poor outcome ( $\mathrm{mRS}$ score $\geq 3)$ compared with $18 \%$ in the younger patients $(p=$ $<0.0001)$, and more patients died in the late-onset group (38\% vs $2 \%, p=<0.0001$; (eFigure 2, links.lww.com/NXI/A674).

\section{Antibody Test Accuracy}

Antibody test accuracy was investigated from May 2015 to December 2019. Within this period, 79 patients with antiNMDAR encephalitis were identified, whereas 21 patients had results that could not be confirmed (by other research techniques).

Accuracy of CSF was superior compared with serum reflected by higher sensitivity percentages, for both CBA and IHC $(p<0.0001)$, whereas specificity was at least similar (Table 3 ). One-third of patients had been missed if only serum would have been tested (sensitivity 68\%). Of 2600 CSF samples, an unconfirmed result was identified in $11(0.4 \%)$.
Specificity was high $(>99 \%)$ in all tests, although these small differences are relevant when testing high volumes. This is reflected by the CBA showing only a moderate positive predictive value (PPV) testing in serum, as $29 \%$ of the positive tests were unconfirmed. In CSF, PPV was seriously better $(88 \%)$ as 11 patients had unconfirmed positivity $(p=0.008$ compared with serum; Table 4$)$. Confirmation with IHC added value to determine clinical relevance, mostly reflected in a lower number of unconfirmed positive results $(p=0.008$ for serum and $p=0.006$ for CSF). This resulted in a higher PPV in both serum (96\%) and CSF (100\%), favoring IHC over CBA.

\section{Patients With Unconfirmed Positive NMDAR Results in CSF}

Eleven patients had an unconfirmed CBA result in CSF for NMDAR antibodies (between 2015 and 2019), considering negative results on both IHC and LN. Similarly, serum from 10 of these patients was tested and showed in 9 of them the 
Table 3 Anti-NMDAR Antibody Tests Accuracy in Serum and CSF Samples

\begin{tabular}{|c|c|c|c|c|}
\hline & \multicolumn{4}{|l|}{ Serum } \\
\hline & NMDARE & No NMDARE & & \\
\hline CBA + & 46 & 19 & 65 & PPV 71\% (60-80\%) \\
\hline \multirow[t]{3}{*}{ CBA - } & 22 & 3,141 & 3,163 & NPV 99.3\% (99.0-99.5\%) \\
\hline & 68 & 3,160 & 3,228 & \\
\hline & Sens 68\% (55-78\%) & Spec 99.4\% (99.1-99.6\%) & & \\
\hline $\mathrm{IHC}+$ & 52 & 2 & 54 & PPV 96\% (87-99.1\%) \\
\hline \multirow[t]{3}{*}{ IHC - } & 19 & 2,215 & 2,234 & NPV 99.2\% (98-99.4\%) \\
\hline & 71 & 2,217 & 2,288 & \\
\hline & Sens $73 \%(61-83 \%)$ & Spec 99.9\% (99.7-99.9\%) & & \\
\hline
\end{tabular}

\begin{tabular}{|c|c|c|c|c|}
\hline & \multicolumn{4}{|l|}{ CSF } \\
\hline & NMDARE & No NMDARE & & \\
\hline $\mathrm{CBA}+$ & 78 & $11^{\mathrm{b}}$ & 89 & PPV 88\% (80-93\%) \\
\hline \multirow[t]{3}{*}{ CBA - } & $1^{b}$ & 2,589 & 2,590 & NPV 99.9\% (99.7-99.9\%) \\
\hline & 79 & 2,600 & 2,679 & \\
\hline & Sens 99\% (93-99.9) & Spec 99.6\% (99.2-99.8) & & \\
\hline $\mathrm{IHC}+$ & 76 & 0 & 76 & PPV $100 \%(-)$ \\
\hline \multirow[t]{3}{*}{ IHC - } & $1^{\mathrm{b}}$ & 1,306 & 1,307 & NPV 99.9\% (99.5-99.9\%) \\
\hline & $77^{\mathrm{a}}$ & 1,306 & 1,383 & \\
\hline & Sens 99\% (93-99.9\%) & Spec 100\% (99.7-100\%) & & \\
\hline
\end{tabular}

Abbreviations: $\mathrm{CBA}$ = cell-based assay; IHC = immunohistochemistry; NMDARE = anti-NMDAR encephalitis; NPV = negative predictive value; PPV = positive predictive value; Sens = sensitivity; $\mathrm{Spec}=$ specificity.

Sensitivity, specificity, PPV, and NPV are depicted as \% $(95 \% \mathrm{Cl})$.

From May 2015 to December 2019, in total 79 patients with anti-NMDAR encephalitis (NMDARE) were identified, and another 21 patients were identified with unconfirmed positive results (No NMDARE).

a One patient with anti-NMDAR encephalitis could not be scored with IHC because of high background (live neurons were positive). Another patient's CSF

could not be tested with IHC because no more CSF was available (this was not the patient with a negative CBA result).

${ }^{\mathrm{b}}$ These patients are elucidated in Table 4.

same combination of positive CBA unconfirmed by alternative research techniques (IHC and LN). Our results were reconfirmed in a reference laboratory. Individual data of all 11 patients are shown in Table 4. Four patients had a psychiatric or neurodegenerative etiology, all without evidence for autoimmunity. Six patients had an inflammatory etiology of disease different from anti-NMDAR encephalitis, and 1 patient had an infectious condition.

\section{Undetectable Serum Antibodies}

Fifteen of the 109 patients (14\%) with available serum had no detectable NMDAR antibodies, tested by both CBA and IHC (eTable 3, links.lww.com/NXI/A674). The other 94 patients had antibodies in both serum and CSF (seropositive) using IHC and/or CBA. Compared with seropositive patients, the seronegative patients were older at disease onset with a median age of 35 vs 23 years $(p=0.016)$. Seronegative patients tended to have less symptoms, although this did not reach statistical significance
(4 compared with a number of 6 symptoms in seropositive patients; $p=0.10$ ). ICU admission was evenly required in both groups. Time to diagnosis and time to start of immunotherapy were similar in both groups, as were functional outcome and relapse rates. The seronegative patients had significantly lower antibody titers in CSF compared with seropositive patients (median 1:8 [IQR 1:2-1:32] vs 1:64 [IQR 1:16-1:256]; $p=$ $0.003)$ and more frequently CSF pleocytosis $(100 \%$ vs $71 \%, p=$ 0.020 ). Two patients (13\%) in the seronegative group had a tumor compared with 26 seropositive patients $(29 \%, p=0.34)$.

\section{Discussion}

This nationwide observational cohort study shows that the CBA to detect NMDAR antibodies performs very well, but not perfectly. This was demonstrated by the finding that patients can have unconfirmed positive results in CSF. Second, 


\begin{tabular}{|c|c|c|c|c|c|c|c|}
\hline $\begin{array}{l}\text { Sex, age at } \\
\text { onset }\end{array}$ & Symptoms & Blood analysis & CSF & $\begin{array}{l}\text { MRI } \\
\text { T2/FLAIR }\end{array}$ & Tumor & EEG & Final diagnosis \\
\hline \multicolumn{8}{|c|}{ Patients with a clinically irrelevant positive anti-NMDAR CBA in CSF } \\
\hline$F, 65$ y & Psychosis & n.p. & Normal, OCB n.p. & n.p. & Not screened & n.p. & Noninflammatory: psychiatric \\
\hline$M, 23 y$ & $\begin{array}{l}\text { Cognitive deterioration and psychosis. Mother } \\
\text { with Huntington disease }\end{array}$ & n.p. & Normal, OCB- & $\begin{array}{l}\text { Less volume nucleus caudatus } \\
\text { both sides }\end{array}$ & Not screened & n.p. & $\begin{array}{l}\text { Noninflammatory: schizophrenia. } \\
\text { Refused Huntington testing }\end{array}$ \\
\hline$M, 65 y$ & $\begin{array}{l}\text { Cognitive and behavioral change, psych sympt, } \\
\text { and aphasia. History of gait disturbance }\end{array}$ & Anti-TPO neg, Tau $\uparrow$ & Normal, OCB n.p. & Normal & No & Slow & $\begin{array}{l}\text { Noninflammatory: Korsakoff-like } \\
\text { syndrome }\end{array}$ \\
\hline$M, 55 y$ & $\begin{array}{l}\text { Behavioral change, apraxia, aphasia, and } \\
\text { psychosis }\end{array}$ & Limited info & Limited info & Limited info & Limited info & Less info & $\begin{array}{l}\text { Noninflammatory: Korsakoff-like } \\
\text { syndrome }\end{array}$ \\
\hline$F, 54$ y & Behavioral change and seizures & ANCA+ (PR3) & Normal. OCB n.p. & $\begin{array}{l}\text { Chronic mastoiditis, intracranial } \\
\text { breakthrough, and Gd+ meninges }\end{array}$ & Not screened & Normal & $\begin{array}{l}\text { Infectious: mastoiditis resulting in } \\
\text { meningitis. Refused referral for PR3 }\end{array}$ \\
\hline F, 57 y & $\begin{array}{l}\text { Progressive muscle strength loss and respiratory } \\
\text { failure }\end{array}$ & n.p. & $\begin{array}{l}\text { WBC 3, Prot } \uparrow \text {, } \\
\text { OCB n.p. }\end{array}$ & n.p. & Not screened & n.p. & $\begin{array}{l}\text { Inflammatory: GBS-AMSAN (NF155 } \\
\text { pos) }\end{array}$ \\
\hline F, 37 y & Vision problems and migraine & n.p. & $\begin{array}{l}\text { WBC } 60 \text {, IgG index } \\
\uparrow, O C B+\end{array}$ & $\begin{array}{l}\text { Multiple white matter lesions with } \\
\text { Gd+ }\end{array}$ & Not screened & n.p. & Inflammatory: RR-MS \\
\hline F, 74 y & $\begin{array}{l}\text { Seizures, cognitive deterioration, and behavioral } \\
\text { change }\end{array}$ & $\begin{array}{l}\text { ANA } \uparrow(320) \text {, anti-dsDNA } \uparrow \text { en } \\
\text { sIL-2R } \uparrow\end{array}$ & Normal, OCB n.p. & $\begin{array}{l}\text { Atrophy, mostly temporoparietal } \\
\text { left }\end{array}$ & No & Normal & $\begin{array}{l}\text { Inflammatory: antiphospholipid } \\
\text { syndrome and corticobasal } \\
\text { degeneration }\end{array}$ \\
\hline M, 55 y & $\begin{array}{l}\text { Seizure, loss of consciousness, cognitive and } \\
\text { behavioral change ( } 3 \text { episodes) }\end{array}$ & $\begin{array}{l}\text { sIL-2R nl. ANA TPO neg, tTG } \\
\text { endomysium normal }\end{array}$ & Normal, OCB- & Normal & No & Normal & Inflammatory: encephalitis \\
\hline M, 71 y & $\begin{array}{l}\text { Cognitive and behavioral change, insomnia, fever, } \\
\text { and myoclonia. Sudden death after } 1 \text { mo }\end{array}$ & & $\begin{array}{l}\text { WBC 66, Prot } \uparrow, \\
\text { OCB n.p. }\end{array}$ & Normal & $\begin{array}{l}\text { Probable } \\
\text { bladder } \\
\text { carcinoma }\end{array}$ & $\begin{array}{l}\text { Diffuse } \\
\text { slow }\end{array}$ & Inflammatory: encephalitis \\
\hline F, 27 y & $\begin{array}{l}\text { Behavioral change, seizures, psych sympt, } \\
\text { dyskinesias, and Sjogren history }\end{array}$ & $\begin{array}{l}\text { ANA, anti-SSA+. SIL-2R mild } \\
\text { raised. Anti-dsDNA normal }\end{array}$ & WBC 7, OCB n.p. & Normal & No & $\begin{array}{l}\text { Diffuse } \\
\text { slow }\end{array}$ & $\begin{array}{l}\text { Inflammatory: encephalitis or neuro- } \\
\text { Sjogren syndrome }\end{array}$ \\
\hline \multicolumn{8}{|c|}{ Patients with anti-NMDAR encephalitis with a negative IHC in CSF } \\
\hline F, 74 y & Post-HSV. Seizures, psych sympt, and aphasia & & $\begin{array}{l}\text { WBC 10, OCB n.p. } \\
\text { LN+ }\end{array}$ & $\begin{array}{l}\text { Post-HSV increased MT } \\
\text { hyperintensity }\end{array}$ & Not screened & $\begin{array}{l}\text { Diffuse } \\
\text { slow }\end{array}$ & Post-HSV NMDAR encephalitis \\
\hline \multicolumn{8}{|c|}{ Patients with anti-NMDAR encephalitis with a negative CBA in CSF } \\
\hline F, 15 y & $\begin{array}{l}\text { Seizures, cognitive and behavioral change, psych } \\
\text { sympt, aphasia, and dystonia }\end{array}$ & & $\begin{array}{l}\text { WBC 9, OCB-. FU } \\
\text { sample NMDAR+ }\end{array}$ & Normal & No & $\begin{array}{l}\text { Epileptic } \\
\text { and slow }\end{array}$ & $\begin{array}{l}\text { Inflammatory: anti-NMDAR } \\
\text { encephalitis }\end{array}$ \\
\hline $\begin{array}{l}\text { Abbreviation } \\
\text { GBS-AMSAN } \\
\text { OCB = oligoc }\end{array}$ & $\begin{array}{l}\mathrm{VA}=\text { antinuclear antibody; } \mathrm{ANCA}=\text { antineutrophil } \mathrm{c} \\
\text { illain-Barre syndrome-acute motor-sensory axon } \\
\text { I band; PR3 = proteinase 3; Prot = protein; psych s }\end{array}$ & $\begin{array}{l}\text {-ytoplasmic antibody; anti-dsD } \\
\text { al neuropathy; Gd+= gadoliniu } \\
\text { sympt = psychiatric symptoms; }\end{array}$ & $\begin{array}{l}\text { NA = anti-double-stra } \\
\text { um enhancement; HS } \\
\text { RR-MS = relapsing-r }\end{array}$ & $\begin{array}{l}\text { anded DNA; anti-TPO = anti-thyroic } \\
5 V=\text { herpes simplex virus; } L N=\text { live } \\
\text { emitting MS; sIL-2R = soluble inter }\end{array}$ & $\begin{array}{l}\text { eroxidase; ant } \\
\text { euron; } \mathrm{MT}=\mathrm{m} \\
\text { kin-2 } \text { receptor }\end{array}$ & $\begin{array}{l}\text { TG }=\text { anti- } \mathrm{t} \\
\text { iotempora } \\
\text { NBC = whit }\end{array}$ & $\begin{array}{l}\text { ssue transglutaminase; FU = follow-up; } \\
\text { neg = negative; n.p. = not performed; } \\
\text { blood cell count. }\end{array}$ \\
\hline
\end{tabular}


anti-NMDAR encephalitis is less rare at older age than previously thought, and these patients have other paraneoplastic associations and a worse outcome. At last, patients without detectable serum antibodies have lower CSF antibody titers, but disease course appeared not to be milder.

Novel within our cohort, we describe a small series of patients without anti-NMDAR encephalitis despite positive CBA results in CSF. A previous review ${ }^{20}$ described the presence of surface antibodies in 1,650 controls and found 16 cases with NMDAR antibodies in CSF by using CBA, but all 16 cases were (retrospectively) assessed to truly have had antiNMDAR encephalitis. We identified 11 patients with unconfirmed CSF antibody results: next to a positive CBA, a positive result by at least 1 additional, different technique was mandatory, and this was not met, despite all samples being tested with 3 different techniques in 2 independent laboratories. As all samples tested positive by both commercial CBA and in-house CBA, it should not be considered simply a falsepositive result. Although we cannot exclude that the antibody result is relevant, we consider clinical irrelevance as the most likely explanation. Seven patients had an inflammatory etiology for their symptoms suggesting that a broader immune response or antibody formation secondary to neuronal damage was present leading to these confusing antibody results. None of the patients fulfilled the criteria for probable antiNMDAR encephalitis, according to the Graus criteria. ${ }^{21}$ In most of these 11 patients, clinical assessment proved to be of great importance as the phenotype was atypical for encephalitis with NMDAR antibodies. Therefore, despite positive antibody results, the physician should remain vigilant and open minded. In case of doubt, CBA result confirmation by a research (reference) laboratory using alternative techniques (IHC and/or LN) is advocated.

Although CSF results can occasionally be difficult to interpret, this is much more frequently an issue in serum, as one-quarter of the positive serum results were considered clinically irrelevant, similar to previous reports. ${ }^{7,22}$ Especially in those with a low pretest probability, the risk to encounter unconfirmed or clinically irrelevant results becomes unacceptably high as reported by earlier studies in healthy controls, psychiatric patients, or patients with CJD. ${ }^{8-14}$ Confirmation in CSF is therefore essential, as CSF was superior to serum in the diagnosis of anti-NMDAR encephalitis, which is in line with previous studies. ${ }^{6,23}$

Except for the high frequency of patients in the age $\geq 45$ years, our cohort showed no discrepancies compared with other NMDAR cohorts. ${ }^{2,4}$ A fifth of our patients would be considered late-onset anti-NMDAR encephalitis compared with only $5 \%$ in earlier reports. ${ }^{4}$ As the differential diagnosis in patients at older age is broader, this probably reflects better awareness of anti-NMDAR encephalitis and a lower threshold to send samples for testing nowadays. Within our cohort, $78 \%$ of the late-onset patients were diagnosed after 2015 compared with $58 \%$ in younger patients, supporting this theory. Earlier it was suggested that late-onset patients had a less severe disease course, ${ }^{4}$ but this was not confirmed in our study. We did confirm a lower frequency of seizures, ${ }^{3,4}$ more frequent antibody-negative results in serum, ${ }^{5}$ and a trend in less female predominance. ${ }^{4}$ All these items culminate in a lower number of symptoms. A higher level of suspicion is therefore necessary to recognize late-onset anti-NMDAR encephalitis, despite the broad differential diagnosis, as the outcome is worse at that age. ${ }^{4}$ Although the time initial immunotherapy was similar in late-onset patients, they tended to have less and later initiation of second-line immunotherapy (both not significant, probably related to the modest sample size). As it is known that brain plasticity and the capacity to recover diminish with age, ${ }^{24}$ better chances for recovery necessitate early and aggressive treatment; especially as this is the factor best amended by physicians. Remarkably, in the patients older than 45 years, only carcinomas were identified, similar to previous publications, ${ }^{4}$ whereas only teratomas were found in younger patients. This emphasizes the importance for a thorough but different tumor workup as FDG-PET/CT is best to detect carcinomas, whereas this is not sensitive to detect teratomas. ${ }^{25}$

We found the same frequency of patients with anti-NMDAR encephalitis without detectable serum antibodies as earlier reports. ${ }^{5,6}$ The lack of serum antibodies was associated with lower antibody titers in CSF. Similarly, these patients were older at disease onset and had fewer tumors. ${ }^{5}$ Although tumor difference was not significant in our cohort, the size and direction were similar to previous study, suggesting a lack of statistical power by sample size. All these observations suggest a less robust immune response, and the absence of detectable serum antibodies might well be a threshold issue. As CSF is diluted less under normal test conditions, and almost all patients show intrathecal antibody synthesis, CSF might provide a better signalto-noise ratio. Lack of antibodies in serum is difficult to imagine, especially in patients with a paraneoplastic disease. In our cohort, 2 malignancies were discovered by tumor screening: 1 was a small-cell lung carcinoma, probably related, and 1 a metastatic esophagus carcinoma, likely a coincidental finding.

The incidence of anti-NMDAR encephalitis was 1 per million per year over the last 5 years. This is in line with the reported incidence in the literature, ranging between 0.7 and 2.2 per million per year, ${ }^{15,26-28}$ although those studies analyzed only children. Over the years, the incidence has increased, and this was likely reflecting increased awareness due to the novelty. However, over the last 5 years, the incidence peaked in 2017, suggesting a currently unknown trigger specific for that year. Over the years, onset of disease seems to cluster in late spring, although this did not reach statistical significance. One study in children has looked at seasonal patterns, also suggesting a predominance of the early warm months. ${ }^{29}$ This association seemed slightly stronger when looking only at idiopathic antiNMDAR encephalitis, similar to the study in children. Neoplasms and herpes simplex encephalitis are the only known triggers of anti-NMDAR encephalitis, ${ }^{17,30,31}$ but the seasonal pattern and yearly varying incidence might suggest environmental triggers, like specific infections. No studies have 
identified consistent infectious triggers. ${ }^{32}$ Despite the intriguing peak in 2017, we were unable to identify a higher incidence of, for example, influenza or influenza-like diseases in the Dutch Institute for Health Services Research (NIVEL) report. Future studies are necessary to elucidate a role for other infectious agents triggering the immune response in anti-NMDAR encephalitis comparing seasonal patterns in larger cohorts from different countries.

Although this study is nationwide, there are some limitations associated with the retrospective design of this study. First, clinical data were sometimes difficult to assess from the documentation, especially follow-up data. However, we could overcome this issue as we saw or interviewed most patients in our clinic or had contact with the treating physician or caregiver. Second, the cohort is relatively modest in size also reflecting the rarity of the disease, yet we could include almost all patients accomplishing nationwide coverage. Because of the retrospective design, the ability to extract detailed functional outcomes was difficult, and we decided, therefore, to use the mRS, despite its limitations. However, as long-term outcome was not the primary scope of our study, the current amount of data was sufficient to achieve our goals.

In conclusion, physicians should be aware that anti-NMDAR encephalitis can occur at all ages and might be less rare later in life than previously anticipated. Complicating factor is the less outspoken nature of the disease in late-onset patients, but early treatment is even more important due to the link with malignancies and as recovery is already slower and less complete. Physicians requesting NMDAR antibody tests should be aware of the pitfalls of the test, including the lower sensitivity and specificity in serum, and the need for CSF confirmation. However, as no test is ever perfect, the physician should always link the clinical phenotype with the antibody results (even in CSF). In doubt, a reference laboratory should serve to confirm or refute the diagnosis.

\section{Acknowledgment}

The authors thank all patients for their participation and all referring physicians. They thank Esther Hulsenboom, Mariska Nagtzaam, Sanae Boukhrissi, and Ashraf JozefzoonAghai for their technical assistance, Esther de Graaff for performing the live neuron staining, and Bart Titulaer for assistance with the circular statistics. The authors thank Josep Dalmau and his laboratory for their confirmatory analyses. M.W.J. Schreurs, R.F. Neuteboom, P.A.E. Sillevis Smitt, J.M. de Vries, and M.J. Titulaer of this publication are members of the European Reference Network for Rare Immunodeficiency, Autoinflammatory and Autoimmune DiseasesProject ID No 739543 (ERN-RITA).

\section{Study Funding}

MT was supported by an Erasmus MC fellowship, has received funding from the Netherlands Organization for Scientific Research (NWO, Veni incentive), ZonMw (Memorabel program), and the Dutch Epilepsy Foundation (NEF 14-19 \& 19-08).

\section{Disclosure}

A.E.M. Bastiaansen, M.A.A.M. de Bruijn, S.L. Schuller, E. Martinez-Hernandez, J. Brenner, M. Paunovic, Y.S. Crijnen, M.J.H.L. Mulder, M.W.J. Schreurs, and E. de Graaff report no disclosures. P.A.E. Sillevis Smitt holds a patent for the detection of anti-DNER and received research support from Euroimmun. R.F. Neuteboom and J.M. de Vries report no disclosures. M.J. Titulaer received research funds for serving on a scientific advisory board of MedImmune LLC and UCB. MT has filed a patent for methods for typing neurological disorders and cancer, and devices for use therein, and has received research funds for consultation at Guidepoint Global LLC and unrestricted research grants from CSL Behring and Euroimmun AG. Go to Neurology.org/NN for full disclosures.

\section{Publication History}

Received by Neurology: Neuroimmunology \& Neuroinflammation August 14, 2021. Accepted in final form November 10, 2021.

Appendix Authors

\begin{tabular}{lll}
\hline Name & Location & Contribution \\
\hline $\begin{array}{l}\text { Anna E.M. } \\
\text { Bastiaansen, } \\
\text { MD }\end{array}$ & $\begin{array}{l}\text { Erasmus MC University } \\
\text { Medical Center, Rotterdam, } \\
\text { the Netherlands }\end{array}$ & $\begin{array}{l}\text { Study design, acquisition } \\
\text { of data, statistical } \\
\text { analysis, interpretation of } \\
\text { data, and draft of the } \\
\text { manuscript }\end{array}$ \\
$\begin{array}{l}\text { Marienke } \\
\begin{array}{l}\text { A.A.M. de } \\
\text { Bruijn, MD, } \\
\text { PhD }\end{array}\end{array}$ & $\begin{array}{l}\text { Erasmus MC University } \\
\text { Medical Center, Rotterdam, Netherlands, currently at } \\
\text { Elisabeth Tweesteden }\end{array}$ & $\begin{array}{l}\text { Acquisition of data and } \\
\text { revision of the manuscript } \\
\text { for content }\end{array}$ \\
& $\begin{array}{l}\text { Medical Center, Tilburg, the } \\
\text { Netherlands }\end{array}$ & \\
\hline
\end{tabular}

Sabine L. University of Amsterdam, Acquisition of data and

Schuller, BSc Amsterdam, the Netherlands revision of the manuscript for content

\begin{tabular}{lll}
\hline $\begin{array}{l}\text { Eugenia } \\
\text { Martinez- } \\
\text { Hernandez, } \\
\text { MD, PhD }\end{array}$ & $\begin{array}{l}\text { Hospital Clínic, University of } \\
\text { Barcelona, Spain }\end{array}$ & $\begin{array}{l}\text { Acquisition of data and } \\
\text { revision of the manuscript } \\
\text { for content }\end{array}$ \\
\hline $\begin{array}{l}\text { Juliëtte } \\
\text { Brenner, MD }\end{array}$ & $\begin{array}{l}\text { Erasmus MC University } \\
\text { Medical Center, Rotterdam, } \\
\text { the Netherlands }\end{array}$ & $\begin{array}{l}\text { Acquisition of data and } \\
\text { revision of the manuscript } \\
\text { for content }\end{array}$ \\
\hline $\begin{array}{l}\text { Manuela } \\
\text { Paunovic, PhD }\end{array}$ & $\begin{array}{l}\text { Erasmus MC University } \\
\text { Medical Center, Rotterdam, } \\
\text { the Netherlands }\end{array}$ & $\begin{array}{l}\text { Laboratory analysis, } \\
\text { acquisition of data, and } \\
\text { revision of the manuscript } \\
\text { for content }\end{array}$ \\
\hline
\end{tabular}

\begin{tabular}{lll}
\hline $\begin{array}{l}\text { Yvette S. } \\
\text { Crijnen, MD }\end{array}$ & $\begin{array}{l}\text { Erasmus MC University } \\
\text { Medical Center, Rotterdam, } \\
\text { the Netherlands }\end{array}$ & $\begin{array}{l}\text { Acquisition of data and } \\
\text { revision of the manuscript } \\
\text { for content }\end{array}$ \\
\hline
\end{tabular}

\begin{tabular}{lll}
\hline $\begin{array}{l}\text { Maxim J.H.L. } \\
\text { Mulder, MD, } \\
\text { PhD }\end{array}$ & $\begin{array}{l}\text { Erasmus MC University } \\
\text { Medical Center, Rotterdam, } \\
\text { the Netherlands }\end{array}$ & $\begin{array}{l}\text { Acquisition of data and } \\
\text { revision of the manuscript } \\
\text { for content }\end{array}$ \\
\hline $\begin{array}{l}\text { Marco W.J. } \\
\text { Schreurs, PhD }\end{array}$ & $\begin{array}{l}\text { Erasmus MC University } \\
\text { Medical Center, Rotterdam, } \\
\text { the Netherlands }\end{array}$ & $\begin{array}{l}\text { Laboratory analysis, } \\
\text { acquisition of data, and } \\
\text { revision of the manuscript } \\
\text { for content }\end{array}$ \\
\hline
\end{tabular}

Esther de University Utrecht, Utrecht, Acquisition of data and

Graaff, PhD the Netherlands revision of the manuscript for content 
Appendix (continued)

\begin{tabular}{lll}
\hline Name & Location & Contribution \\
\hline $\begin{array}{l}\text { Peter A.E. } \\
\text { Smitt, MD, PhD }\end{array}$ & $\begin{array}{l}\text { Erasmus MC University } \\
\text { Medical Center, Rotterdam, } \\
\text { the Netherlands }\end{array}$ & $\begin{array}{l}\text { Acquisition of data and } \\
\text { revision of the manuscript } \\
\text { for content }\end{array}$ \\
\hline $\begin{array}{l}\text { Rinze F. } \\
\text { Neuteboom, } \\
\text { MD, PhD }\end{array}$ & $\begin{array}{l}\text { Erasmus MC University } \\
\text { the Netherlands }\end{array}$ & $\begin{array}{l}\text { Acquisition of data and } \\
\text { revision of the manuscript } \\
\text { for content }\end{array}$ \\
$\begin{array}{l}\text { Juna M. de } \\
\text { Vries, MD, PhD }\end{array}$ & $\begin{array}{l}\text { Erasmus MC University } \\
\text { the Netherlands }\end{array}$ & $\begin{array}{l}\text { Acquisition of data and } \\
\text { revision of the manuscript } \\
\text { for content }\end{array}$ \\
\hline $\begin{array}{l}\text { Maarten J. } \\
\text { Titulaer, MD, } \\
\text { PhD }\end{array}$ & $\begin{array}{l}\text { Erasmus MC University } \\
\text { Medical Center, Rotterdam, }\end{array}$ & $\begin{array}{l}\text { Study design, study } \\
\text { supervision, } \\
\text { the Netherlands }\end{array}$ \\
& & $\begin{array}{l}\text { interpretation of data, } \\
\text { statistical analysis, and } \\
\text { revision of the manuscript } \\
\text { for content }\end{array}$ \\
\end{tabular}

\section{References}

1. Titulaer MJ, McCracken L, Gabilondo I, et al. Treatment and prognostic factors for long-term outcome in patients with anti-NMDA receptor encephalitis: an observational cohort study. Lancet Neurol. 2013;12(2):157-165.

2. Irani SR, Bera $\mathrm{K}$, Waters $\mathrm{P}$, et al. N-methyl-D-aspartate antibody encephalitis: temporal progression of clinical and paraclinical observations in a predominantly nonparaneoplastic disorder of both sexes. Brain. 2010;133(Pt 6):1655-1667.

3. Viaccoz A, Desestret V, Ducray F, et al. Clinical specificities of adult male patients with NMDA receptor antibodies encephalitis. Neurology. 2014;82(7):556-563.

4. Titulaer MJ, McCracken L, Gabilondo I, et al. Late-onset anti-NMDA receptor encephalitis. Neurology. 2013;81(12):1058-1063.

5. Guasp M, Módena Y, Armangue T, Dalmau J, Graus F. Clinical features of seronegative, but CSF antibody-positive, anti-NMDA receptor encephalitis. Neurol Neuroimmunol Neuroinflamm. 2020;7(2):e659.

6. Gresa-Arribas N, Titulaer MJ, Torrents A, et al. Antibody titres at diagnosis and during follow-up of anti-NMDA receptor encephalitis: a retrospective study. Lancet Neurol. 2014;13(2):167-177.

7. Zandi MS, Paterson RW, Ellul MA, et al. Clinical relevance of serum antibodies to extracellular N-methyl-D-aspartate receptor epitopes. J Neurol Neurosurg Psychiatry. 2015;86(7):708-713.

8. Dahm L, Ott C, Steiner J, et al. Seroprevalence of autoantibodies against brain antigens in health and disease. Ann Neurol. 2014;76(1):82-94.

9. Zandi MS, Irani SR, Lang B, et al. Disease-relevant autoantibodies in first episode schizophrenia. J Neurol. 2011;258(4):686-688.

10. Mackay G, Ahmad K, Stone J, et al. NMDA receptor autoantibodies in sporadic Creutzfeldt-Jakob disease. J Neurol. 2012;259(9):1979-1981.

11. Masdeu JC, Dalmau J, Berman KF. NMDA receptor internalization by autoantibodies: a reversible mechanism underlying psychosis? Trends Neurosci. 2016;39(5): 300-310
12. Grau-Rivera O, Sanchez-Valle R, Saiz A, et al. Determination of neuronal antibodies in suspected and definite Creutzfeldt-Jakob disease. JAMA Neurol. 2014;71(1):74-78.

13. Steiner J, Walter M, Glanz W, et al. Increased prevalence of diverse N-methyl-Daspartate glutamate receptor antibodies in patients with an initial diagnosis of schizophrenia: specific relevance of IgG NRla antibodies for distinction from N-methyl-D-aspartate glutamate receptor encephalitis. JAMA Psychiatry. 2013;70(3) 271-278

14. Kayser MS, Titulaer MJ, Gresa-Arribas N, Dalmau J. Frequency and characteristics of isolated psychiatric episodes in anti-N-methyl-d-aspartate receptor encephalitis. JAMA Neurol. 2013;70(9):1133-1139.

15. de Bruijn M, Aarsen FK, van Oosterhout MP, et al. Long-term neuropsychological outcome following pediatric anti-NMDAR encephalitis. Neurology. 2018;90(22): e1997-e2005.

16. Ances BM, Vitaliani R, Taylor RA, et al. Treatment-responsive limbic encephalitis identified by neuropil antibodies: MRI and PET correlates. Brain. 2005;128(Pt 8) 1764-1777.

17. Dalmau J, Gleichman AJ, Hughes EG, et al. Anti-NMDA-receptor encephalitis: case series and analysis of the effects of antibodies. Lancet Neurol. 2008;7(12):1091-1098.

18. van Swieten JC, Koudstaal PJ, Visser MC, Schouten HJ, van Gijn J. Interobserver agreement for the assessment of handicap in stroke patients. Stroke; a J Cereb Circ. $1988 ; 19(5): 604-607$

19. Fisher NI. Statistical Analysis of Circular Data. Cambridge University Press; 1993.

20. Lang K, Prüss H. Frequencies of neuronal autoantibodies in healthy controls: estimation of disease specificity. Neurol Neuroimmunol Neuroinflamm. 2017;4(5):e386.

21. Graus F, Titulaer MJ, Balu R, et al. A clinical approach to diagnosis of autoimmune encephalitis. Lancet Neurol. 2016;15(4):391-404.

22. Armangue T, Santamaria J, Dalmau J. When a serum test overrides the clinical assessment. Neurology. 2015;84(13):1379-1381.

23. Hara M, Martinez-Hernandez E, Ariño $\mathrm{H}$, et al. Clinical and pathogenic significance of IgG, IgA, and IgM antibodies against the NMDA receptor. Neurology. 2018;90(16): e1386-e1394.

24. Lövdén M, Wenger E, Mårtensson J, Lindenberger U, Bäckman L. Structural brain plasticity in adult learning and development. Neurosci Biobehav Rev. 2013;37(9 Pt B) 2296-2310.

25. Titulaer MJ, Soffietti R, Dalmau J, et al. Screening for tumours in paraneoplastic syndromes: report of an EFNS task force. Eur J Neurol. 2011;18(1):19-e3.

26. Boesen MS, Born AP, Lydolph MC, Blaabjerg M, Børresen ML. Pediatric autoimmune encephalitis in Denmark during 2011-17: a nationwide multicenter populationbased cohort study. Eur J Paediatr Neurol. 2019;23(4):639-652.

27. Wright S, Hacohen Y, Jacobson L, et al. N-methyl-D-aspartate receptor antibodymediated neurological disease: results of a UK-based surveillance study in children. Arch Dis Child. 2015;100(6):521-526.

28. Ho AC, Chan $\mathrm{SH}$, Chan E, et al. Anti-N-methyl-d-aspartate receptor encephalitis in children: incidence and experience in Hong Kong. Brain Dev. 2018;40(6):473-479.

29. Adang LA, Lynch DR, Panzer JA. Pediatric anti-NMDA receptor encephalitis is seasonal. Ann Clin Transl Neurol. 2014;1(11):921-925.

30. Nosadini M, Mohammad SS, Corazza F, et al. Herpes simplex virus-induced anti-Nmethyl-d-aspartate receptor encephalitis: a systematic literature review with analysis of 43 cases. Dev Med Child Neurol. 2017;59(8):796-805.

31. Armangue T, Spatola M, Vlagea A, et al. Frequency, symptoms, risk factors, and outcomes of autoimmune encephalitis after herpes simplex encephalitis: a prospective observational study and retrospective analysis. Lancet Neurol. 2018;17(9):760-772.

32. Gable MS, Sheriff H, Dalmau J, Tilley DH, Glaser CA. The frequency of autoimmune $\mathrm{N}$-methyl-D-aspartate receptor encephalitis surpasses that of individual viral etiologies in young individuals enrolled in the California Encephalitis Project. Clin Infect Dis. 2012;54(7):899-904. 


\title{
Neurology \\ Neuroimmunology \& Neuroinflammation
}

\author{
Anti-NMDAR Encephalitis in the Netherlands, Focusing on Late-Onset Patients and \\ Antibody Test Accuracy \\ Anna E.M. Bastiaansen, Marienke A.A.M. de Bruijn, Sabine L. Schuller, et al. \\ Neurol Neuroimmunol Neuroinflamm 2022;9; \\ DOI 10.1212/NXI.0000000000001127
}

This information is current as of December 22, 2021

\section{Updated Information \& \\ Services}

References

Subspecialty Collections

Permissions \& Licensing

Reprints including high resolution figures, can be found at:

http://nn.neurology.org/content/9/2/e1127.full.html

This article cites 31 articles, 4 of which you can access for free at: http://nn.neurology.org/content/9/2/e1127.full.html\#\#ref-list-1

This article, along with others on similar topics, appears in the following collection(s):

Autoimmune diseases

http://nn.neurology.org//cgi/collection/autoimmune_diseases

Encephalitis

http://nn.neurology.org//cgi/collection/encephalitis

Information about reproducing this article in parts (figures,tables) or in its entirety can be found online at:

http://nn.neurology.org/misc/about.xhtml\#permissions

Information about ordering reprints can be found online:

http://nn.neurology.org/misc/addir.xhtml\#reprintsus

Neurol Neuroimmunol Neuroinflamm is an official journal of the American Academy of Neurology.

Published since April 2014, it is an open-access, online-only, continuous publication journal. Copyright

Copyright (C) 2021 The Author(s). Published by Wolters Kluwer Health, Inc. on behalf of the American

Academy of Neurology.. All rights reserved. Online ISSN: 2332-7812.

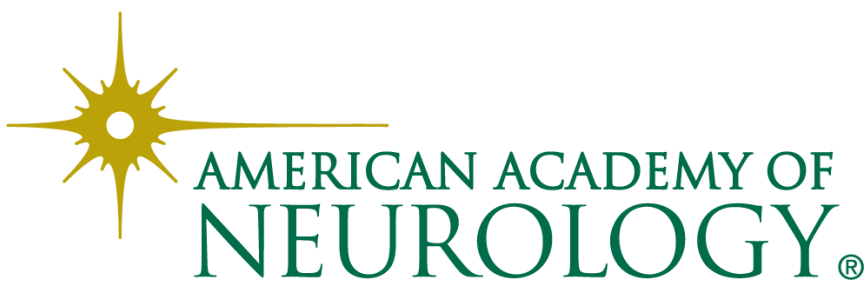

